\title{
Angels, Warriors and Beacons.
}

\section{Totemic Law, Territorial Coding, and Monumental Sculpture in Post-Industrial Landscapes.}

\author{
Ronnie Lippens \\ Professor of Criminology \\ Keele University (UK)
}

\begin{abstract}
National or local authorities regularly commission artists to build or construct sculptures and artworks destined for a place in a public space. Some of those sculptures and artworks are monumentally huge. Positioned in the open landscape, they are visible from a considerable distance. This contribution focuses on three such sculptures in the United Kingdom. The first, 'Angel of the North', was completed in 1998 and is standing at Gateshead in the North East of England. The second, 'Anglo Saxon Warrior', has not yet been built to a massive scale -although smaller, life-size versions were- but some debate has taken place in Stoke-on-Trent in North Staffordshire in the West Midlands about the possibility and remote likelihood of its construction. The third, 'Golden', is, however, at the time of writing, in the process of being assembled with an eye on erecting it, in 2014, at the very same location, Stoke-on-Trent. Proposals for all aforementioned artworks emerged against the backdrop of regional de-industrialisation and were, at least partly, devised as an answer to economic and social deprivation in both regional localities. In this contribution an effort is made to tease out the symbolic intricacies embedded in all three artworks. Although all include references to what could be called the eternal origins of a mythical common law universe, each suggests, projects, and attempts to encode a moral and legal order in quite distinctly different ways.
\end{abstract}

\section{Keywords}

monumental sculpture - public art - totemic law - territorial coding - the Angel of the North - post-industrialisation - Gateshead - Stoke-on-Trent

\section{Bio}

Ronnie Lippens is Professor of Criminology at Keele University (Staffordshire, UK). His research interests straddle themes in visual culture on the one hand, and problems and issues of law, governance and justice on the other. He has published prolifically on those topics in a wide variety of venues. 


\section{Public art, introductory notes}

In this essay an attempt will be made to explore how monumental landscape sculpture has emerged, in recent times, in the United Kingdom. In most cases the sculptures, of very considerable size and proportion (they are, typically, around $60 \mathrm{ft}$ or 20 meters high), are being planned, or have already been built and erected, against the backdrop of recent regional histories of de- and post-industrialisation and subsequent economic downturn, social despair, and raised hopes. The often openly avowed raison d'être of the sculptures is for the artworks to serve as a focal point for the expression of a region's predicament and, more specifically, the acknowledgement therein, in the face of adversity, and with some defiance, of its historical accomplishments and potential, whether spent or unspent.

In this essay we shall focus on three such sculptures. The first, the $60 \mathrm{ft}$ Angel of the North, was erected in 1998 in Gateshead, in the postindustrialising North-East of England. The second, Anglo-Saxon Warrior has as yet not been built. It originated in the imagination of a number of local residents of what many would describe as one of the most deprived de-industrialised areas of Britain, i.e. the city of Stoke-on-Trent in North Staffordshire. There the $60 \mathrm{ft}$ version of the Anglo-Saxon Warrior pops up regularly in local presses. The third sculpture however, i.e. the $61 \mathrm{ft}$ Golden, which has been described as a "beacon", is scheduled to be erected in 2014 in that very same Stoke-on-Trent and is, at the time of writing, being assembled locally. We shall of course return to 
those sculptures, real and imagined, below. Suffice here to stress that the aim of the contribution at hand is to argue how such monumental sculptures can be seen and analysed as material manifestations of what could be called 'totemic law'. By that I mean that monumental landscape sculptures do not just carry in them, expressively, the traces of attempts to establish coherence across a variety of perceived or supposed cultural and social codes. In their totemic shapes which, casting shadows wide and far, tend to project their attempted coherence onto the very earth of the expanse of their territory, their totemic 'law' also has more productive dimensions. That is, the sculptures also lay down the law of the land in a normative way. They mark territories. They bind territories under a law that says "This is what we are and this is how we should be. This is the law of this land, in this very landscape". We shall return to these issues in due course. But first we need to note that monumental landscape sculpture is a form of public sculpture, or 'public art' i.e. sculpture or art that is situated in publically accessible open spaces (e.g. parks, street corners, plazas, market squares, or indeed the open landscape). As we shall later see, monumental landscape sculptures are a special and peculiar kind of public sculpture.

Throughout the $19^{\text {th }}$ and early $20^{\text {th }}$ centuries though most public sculptures were placed in urban environments and, in their portrayals of nationally relevant figures or themes, either implicitly or explicitly projected, or attempted to engender, supposed but nearly always 
contested (Levinson 1998) national values and national identity. After the Second World War though public sculpture became much more 'site-specific', i.e. the artwork is very often expected to stand in a relationship with the locality in which it is placed, with the historical or physical characteristics of their immediate environment (city, neighbourhood, street, plaza, or office building), or even with a particular idea or concept or mere notion that has local resonance (Kwon 1997). One of the main reasons and justifications for sitespecificity in public sculpture is to be found in the often acknowledged assumption that such artwork may help to re-generate localities by attracting inward investment (capital investment, consumer spending, affluent residence, etc). While research indicates that site-specific public sculpture on its own could not lead to the re-generation of particular urban places or areas (Selwood 1995; Miles 2005) there seems to be ample evidence that shows that 're-generation' efforts (and some of those of course will include the siting of public art and sculpture) in practice nearly always, and almost inevitably -in a logic of freely moving capital and investment, that is- lead to processes of gentrification and, subsequently, to "uneven development" and "eviction" (Deutsche 1996: xi-xxiv; see also Miles 1997; for a focus on the visual in processes of urban management and urban evictions, see Wagner, 2011). In itself that would already make the deployment of public sculpture in re-generation strategies problematic, if not suspect. But there is more. 
'Site-specificity' can mean a number of things. It can refer to the 'beautification' of particular places. It can also refer to the need for artists to take account of and possibly reflect, in their work, the physical, economic, social or cultural characteristics of the surrounding area and the communities therein. Sometimes the phrase just means to express a desire for the artworks to contribute to the overall well-being of the populations that cross or live in its surrounding space, or to support and enhance the functionality of a particular set of activities and operations that take place in them. But the phrase has also prompted artists to erect, in public places, artwork that deliberately aims to confront and unsettle local functionalities or sensibilities. Richard Serra's minimalist sculpture Tilted Arc is a case in point (see e.g. Kelly 2001; Levine 2002). Serra was commissioned by the US Art-inArchitecture programme to build a work destined for the Federal Plaza in Manhattan. The work was completed and placed in situ in 1979. It consisted of a Cor-Ten steel plate, slightly curved, and slightly tilted, about 120 feet long, and 12 feet high. It blocked the view of users of the plaza and, many claimed, it also hindered the flow of pedestrian traffic. The sculptor, Serra, maintained that the sculpture was an artistic and therefore highly critical and necessarily unpopular comment on and indictment of what he believed to be the unacceptably dominant functionalities of capital and government that were all too visible in the glass-and-concrete office buildings that towered over the area. After a long and protracted legal battle, initiated and spearheaded by 
members of the local legal community, the artwork was ultimately removed in 1989.

The case sparked a fierce debate not just in the US, but across much of the global art world, on the need for commissioning bodies and artists to balance the desire for artistic originality (or 'quality') against the need to heed, or to at least engage with users' and residents' opinions and wishes e.g. through education, or by allowing them a say in the commissioning process, by encouraging them to actively participate in artistic activities, or still, by opting for temporary artworks instead of permanent ones, which, it is then hoped, would allow for much more diversity, voice and counter-voice, and dialogue in public spaces (Phillips 1989; but see Princenthal 2003, for a different view). Most commissioning bodies (see e.g. Cruikshank and Korza 1988; Hamilton et al. 2001) as well as art critics (e.g. Fleming and Goldman 2005), artists themselves (e.g. Blum et al. 1989; Diamond 2004) and scholars (e.g. Burk 2006; Beunders 2007; Cordes and Goldfarb 2007; Clements 2008; Pollock and Paddison 2010; Visconti et al. 2010; Jancovich 2011) have, in the post-Tilted Arc era, become acutely aware of these issues. Let us, with an eye on what is to follow in the remainder of this essay, focus on one of the prominent voices in those debates: Rosalyn Deutsche.

In what has now become a classic work, Evictions (1996), Deutsche, inspired by the literature on radical democracy which, one could argue, dominated 1990s humanities and social sciences debates, came to realise that there is not such a thing as a 'public space' or a 
'public sphere' if by those words is meant a 'space' or a 'sphere' that would operate according to particular (e.g. 'universal') codes (e.g. 'objectivity is possible here', or 'democratic consensus is possible here', or still 'here it is agreed that consensus is desirable'). Focussing on the writings of Claude Lefort, Deutsche, moving rapidly beyond some of her earlier Marxist and feminist convictions, suddenly comes to accept that words such as 'public', 'art', 'particular', 'universal', 'consensus', 'agreement', 'sphere', 'space', 'democracy', 'neutrality', 'impartiality', 'aesthetics', 'beauty', 'functionality', and so on all rest upon nothing but the bottomless, foundation-less void out of which they flowed. This void is both the condition of possibility and the condition of impossibility of the social, and cannot be closed. The void can do nothing but generate multiplicity and contestation upon multiplicity and contestation. The process of incessant multiplication and diversification cannot be stopped. The potential for conflict is always present. Very concretely: anything that emerges in market squares, whether on plinths or not, carries within itself the potential for conflict and contestation. The products of artistic "vanguardism" and political activism carry within them the seeds of contestation and, therefore, of their own eventual destruction (1996: 268, 313-314). But so do the products of commissioning bureaucrats, community activists, capitalist investors, worshippers of peace and calm, outlaws, revolutionaries, and admirers of neat functionality. Each produces work that "evicts" that which, given a little time, will come back to haunt them. There is no 
escape here. Of course attempts are made, unrelentingly one might add, to put a stop to the constant barrage of contestation and multiplication. The desire for 'consensus' and for 'agreement' is indeed one of the products of the void that underpins human sociality. But neither 'consensus' nor 'agreement' could ever be guaranteed. Stronger still, Deutsche, reading the body of literature that goes under the name of radical democracy, realizes: 'consensus' and 'agreement' are really not all that desirable in the first place. 'Democracy' grinds to a halt precisely at the point where or when someone says, or presumes: 'We have reached an agreement. Consensus has been achieved'. Deutsche, then, disagrees firmly with those that "take for granted that [to be] democratic is to presume that the task of democracy is to settle, rather than sustain, conflict" (1996: 270). She writes, still referring to Claude Lefort, that "democracy is instituted and sustained by the dissolution of the marks of certainty" (1996: 270; italics in the original). Anything that presents itself as a "mark of certainty" (e.g. a work of "art" in a "public" "space") is only a mere bump on the road to inevitable contestation. Themselves products of conflict, "art", "public" and "space", can only lead to more conflict, and to the perpetuation of the void at the heart of human sociality. It is this radical democratic insight that we shall explore and apply in the study of the three aforementioned public artworks (the Angel of the North, the Anglo-Saxon Warrior, and Golden). But here again we should make an effort not to rush into the specifics of these artworks. First we 
need to expand on how it is that public artworks, as well as their contestation, emerge out of the bottomless pit of human conflict. We shall do that in the next section. Then we need to explore how public art, monumental landscape sculpture in particular, can be viewed as instances of 'totemic law'. That is the topic of the third section. The analysis of the three sculptures shall then take place in both subsequent sections. We close with a number of concluding remarks.

\section{Forces clashing, art emerging}

Above we have used the word 'void'. That is just a word. There are other words to denote the lack of foundations in the human condition. In Bergsonism for example, which, itself inspired by Spinoza's philosophy, would later go on to underpin much in Deleuze and Guattari's post-structuralism, the ground of all life is to be found in the intensive excess of what Bergson called the élan vital (Bergson 1907). This 'vital current' has an unstoppable momentum that exceeds anything that is generated by it. This momentum is actually an incessantly creative process that takes place on three levels. On the deepest level, the plane of immanence, life consists of pure intensities, that is, affects generated by flows of desire that clash. The flows of desire constitute an unlimited reservoir of pure potential. The flows stretch and span across the whole of life in enigmatic, unpredictable, or rhizomatic ways (on this, see Deleuze and Guattari, 1980) and clash incessantly. These clashes in turn generate clusters of possibility on the 
next level, the level of the virtual. On this level the original potential of the élan vital which at the plane of immanence remains rhizomatically complex and indeterminate, or excessive, thus generates clusters of possibility which somehow reduce the infinite vastness of the intensive energy of life to virtual clusters of possible effects. The virtual clusters in turn then generate material effects (a concept, a song, a book, a sculpture, a museum, a car, and so on) on the third level, i.e. the level of the extensive. And to close the circle: these effects that take place in the sphere of the extensive will then generate more affects at the level of the intensive. And so on.

In this view a work of art travels from intensive affect to extensive effect and back again. But so do our readings and interpretations of the artwork in the extensive. There too the momentum of the élan vital begins with the clash of flows of desire at the level of the intensive (that is: with aesthetic affect), then creates virtual nodes of possibility (a code that is beginning to structure the argument and judgment), and, finally, particular extensive effects (e.g. strings of conceptual materials). We shall return to these issues later. The points that are made here though hold that anything that is created in life, and by life, originates in intensive affect, travels through the virtual, and generates extensive effects which in turn lead back again to intensive affect. They also imply that the process of creation which, it could be said, is just another name for the élan vital, takes place in and through clashes of forces on all levels. What we experience only came about as a result of forces 
clashing. What those experiences in turn generate will in turn emerge in a process whereby forces clash. The third and final point that is made here suggests that what occurs at the level of the extensive could never exhaust its virtual possibilities let alone the vast, infinite fullness of the vast, infinitely complex vat of pure, intensive potential whence it came. Take the critic's judgment. It could never exhaust the infinite pool of intensive potential out of which the work of art emerged. Nor could the critic's judgment ever hope to exhaust the infinite pool of intensive potential out of which it came itself. Indeed, the origins of life's events are inexhaustible. They stretch, rhizomatically, into infinity. In Bergsonism, life at the level of the extensive is the life of images. What emerges at the level of the extensive is a mere effect, a partial image, a fragment temporarily frozen in time and space, of the intensive energies that generated it. The car is an image. The song is an image. The sculpture is an image. The critic's paper is an image. It is an image of an image, to be more precise. The spectator's smile before the sculpture is an image. Its intensive origins loom, and live, inexhaustibly excessive, behind its extensive surface.

In one of his later works, Les deux sources de la morale et de la religion (1932), Bergson is at pains to explain how the gap between on the one hand the intensive affects that we experience and, on the other, our extensive attempts to get to grips with them, is destined to remain just that: a gap. No amount of extensive grappling could ever close the gap between the excessiveness of the intensive affect and the limited 
images of it -i.e. our grappling attempts- that are generated at the level of the extensive. Human beings though cannot but make attempts to fill that gap. They do that by constantly "fabulating". Human beings will tend to fabulate the gap away. The sculptor fabulates his sculpture. The critic fabulates his piece. The spectator, smiling, fabulates his reading of the work. Their fabulations only give them some very temporary stability and reprieve though. It's only a matter of time before excessive affective intensity will once again spill over the fabulated images, un-settling any illusion of stability or closure. This is very similar to what Rosalyn Deutsche, inspired by the literature on radical democracy, wrote about in 1996. Both the artwork and our attempts to grapple with it, Deutsche implied, rest on a nonfoundational plinth, or a void, that could never be closed. Bergson would never have used the word "void" though. In fact, Bergson (1911: 213-229) always maintained that the mere notion of the void is itself only a fabulated image. The void, says Bergson, is just an illusory effect of memory. Where Bergson, the philosopher, and Deutsche, the radical art theorist, would agree though is this: that human creativity flows from and flows back into the vast, infinite indeterminacy of life. All attempts to halt this indeterminacy, whether through fabulation, coercion, eviction, or democratic intervention, will lead to failure. The indeterminate momentum of life will not be halted.

The potentiality of the artwork's origins, or the artwork's potential, always exceeds the artwork (a mere image) itself. The artwork itself 
always exceeds anything (mere images of images) that it gives rise to in turn. This excess can not be halted. Fragments, or images of it, can and will, given time, spill into the extensive dimension of life. It may now be very tempting to say that we should no longer speak then of art. But speak of art we must. Not because we would wish to close the gap that Bergson wrote about, or the void that Deutsche was intrigued by. On the contrary: we must speak about art because we need to keep the gap, or the void, open. As Nicholas Davey (2005) writes, it is precisely because the meaning of art (the image of the image, one could say) is and will for ever remain open, that we must speak about it. We must speak about art and about the work of art precisely because there is an inevitable "f(r)iction" (Davey's telling phrase) between aesthetic experience and our attempts to grapple with it, hermeneutically and conceptually. This notion of an inevitable and ineradicable toing-and-froing friction between aesthetic experience and conceptual representation, it should be noted in passing, finds serious support in experimental psychology (see on this e.g. Leder et al. 2004). But to return to our point: to stop the debate about art, to stop conflict, to stop the clash of forces, to halt the friction, to close the gap, is to coerce and evict. There is however another reason why we should speak about art and about the work of art. A mere image it may be, but the work of art is not just pure expressive image. The work of art projects itself onto the world. It desires. The Angel of the North desires to affect, intensively. It desires affection. The work of art itself speaks. The 
Anglo-Saxon Warrior communicates. It desires effect, extensively. The sculpture Golden wants to achieve aims and goals, whether explicitly stated, implicitly harboured or unconsciously active. The work of art, in short, has forward momentum.

The work of art has intentionality about it, and prompts responsive reaction. Public art does so arguably to a greater extent than other forms of art. However, there is in our view a difference between forms of public art which we need to explore here. As scholars such as Malcolm Miles (1997) have been able to demonstrate, public art in urban settings is very often part of broader attempts to partition the urban space into specific zones ("zoning") whereby each zone is given a certain functionality, supported by matching aesthetic forms which, it is then hoped, will attract the right kind of residents or visitors or activity, and "evict" (Deutsche's word) others. Urban public art, then, is largely a work of division and exclusion. However, public art that is sited in the open landscape, and especially monumentally-sized landscape sculpture, may differ in this respect. Monumental landscape sculpture is not so much a work of intended division and inclusion, but, rather, of collection, and even integration. Towering over the wide variety of populations and infrastructures in the surrounding landscape, the monument gathers and covers all under its cloak-like shadow. From on high, it projects its unifying law onto the land. Let us be clear: the law of the land, it too, is a work of eviction and exclusion. All law is. But whereas most "zoning" urban public art has something of the carving 
knife about it, monumental landscape sculpture is more like the platter on which the carved pieces rest.

\section{Territory, code and totemic law}

The essay at hand wants to contribute to what Anne Barron (2000) has termed "spectacular jurisprudence". But whereas Barron focuses on the spectacular (or visual) elements in or visual manifestations of law and jurisprudence, the issue here, in this contribution, is, rather, to tease out normative codes and orders (however imaginary and however implicit those orders) from works of art. Of course, in light of what we have explored above, any such attempt at teasing out normative codes and orders could only ever be partial, non-exhaustive, merely speculative, i.e. a mere image of an image. But for reasons that will become clear soon enough, it is worthwhile to make the effort.

In an essay on the "moral space" of works of art Benjamin Tilghman (2006: 51-60) makes the claim that Renaissance art introduced, on canvas, space for the narrative evocation of ethical relation and moral interaction. This, he adds, has been lost with the advent of modern abstract art. The latter no longer includes "moral space". Be that as it may, the notion of "moral space" is interesting. One could say (pace Tilghman) that all work of art radiates a moral space. To repeat: although particular, and bound to the extensive form of the work of art, this moral space will nevertheless be open for multiple readings and interpretations. The point that is made here though is simply this: that 
the work of art, originating from a clash of forces, that is, from intensive flows of desire, from virtual nodes of possibility, and from extensive articulations of matter, emerges into the world with a forward thrust that not just holds an exclamation "it is thus", but also, and perhaps more importantly, a "thus it should and must be". The work of art is always also about the "making and shaping of places and people", to use Harriet Hawkins' words (2012: 57). Even the Arts Council of England takes it for granted that "the sense of identity and purpose" of "individuals [...] neighbourhoods, communities, regions and entire generations [...] can be changed through art" (cited in Belfiore and Bennett 2007: 226). There is more than a fleeting similarity here, it should be noted in passing, with desire-fuelled, "power-gaming" and explicitly normative images such as those in ubiquitously present, sometimes numbing, sometimes disorientating, and sometimes re-orientating advertising (see e.g. Wagner 2014).

There is a code, an order, or a collection of codes and orders, embedded in the public work of art, particularly in monumental landscape sculpture. Soaring high above the landscape, the sculpture draws its energy from the infinitely complex reservoir of potential in the soil on which it is grounded, and which, in the clash of forces, had been virtually reduced to bundles of coded possibility before it ultimately crystallized in matter, in the sphere of the extensive where it is now radiating its hidden codes across its landscape, towards the fields, buildings, roads, and bodies on its territory. Seen this way the sculpture 
on the one hand expresses the law of the land (i.e. the codes embedded in its matter are drawn from the energetic soil on which it stands) while at the same time it also lays down the law of the land (i.e. it radiates the code outward). In other words: on the one hand the sculpture merely expresses the law of the land. In the words of a Milanese resident, one of Luca Visconti and colleagues' interviewees (who spoke about street art): "to me [...] [it is] a way to experience the deep soul of urban places, a kind of tribal conscience" (Visconti et al 2010: 519). On the other hand, and paradoxically so, it also imposes the law of the land onto its possibly reluctant surroundings. As artist Patricia Johanson wrote, "Built projects [...] should provide a sense of order and orientation and be designed as a framework in which both people and other living things can exist". She continues, "our environment [...] is a major force in determining who we are and what we shall become" (in Blum at al. 1989: 338).

The paradox should not come as a surprise. The forward momentum of life (or becoming) is inevitably paradoxical, both expressive and transformative. So is art. So is law. In his book on the "grounds of law" Peter Fitzpatrick (2001) revisits Freud's mythology on the origins of human sociality, Totem und Tabu. The totem, Fitzpatrick argues, is erected out of remorse, and as part of a mourning process. At some point the primordial horde no longer tolerated being subjected to the savage ruler's brutal, whimsical rule. They decided to kill the ruler. But no sooner is this feat accomplished than they mourn the loss of rule. 
And thus they erect the totem which in a way also represents the slain ruler of yore, the original legal authority so to speak. With the totem a primitive, inaugural system of normative sociality and legal authority emerges. But the new law, or totemic law, carries within it traces of what went before, i.e. savage rule, since of course the totem is itself built on what could be termed savage bloodshed. And so it is with the newly emerged social collective. It emerged in the wake of the ruler's demise, but in a way it must already have existed before, e.g. at the point when the horde decided to decide, collectively, to slay the ruler and to abandon their savagery. The old, so to speak, is in the new, but the new was already in the old. The totem, or totemic law, expresses both savagery and sociality. But by the same token it is also a work of transformation. The totem, around which the territorial tribe is gathered, does then not just express their determined will to live a socially and legally bounded life, it also attempts, and continuously attempts to bind the always potentially indeterminate (or potentially savage) tribal members to the law of the tribe and its territory. In the process it transforms their lives into socially and legally sanctioned ones. Let there be no doubt, this is a coercive process. This is always, and inevitably so, a process of "taboos" and "evictions".

But that is totemic law. What about monumental landscape sculpture? There may not be a lot of coincidence in the fact that, in the United Kingdom at least, most, if not all monumental landscape sculptures were erected in seriously de-industrialized and, which varying success, 
post-industrializing regions. There are, as we shall see, undoubtedly elements both of mourning and tentative transformation involved in all of them. Elements of the old law, that is, of the old "way of life" in industrial times and communities, are nostalgically embedded in many of the sculptures. Nostalgia should not come as too much of a surprise in an age when even radical, "vanguardist" spatial practices such as those deployed by psycho-geographical situationism often manifest nostalgia (Bonnett 2009). But the codes in the sculptures are also transformative. Their transformative aspect also must have been dwelling, perhaps only fragmentary, at the point when a tribal decision was reached, in the local earth, i.e. in the reservoir of potential on which the sculpture stands and from which it emerged in a clash of forces. The sculpture's codes, its totemic law, then, are also about organizing the territory and ordering the populations in it. They are geared towards the production and construction of a social, moral and legal order.

This is no news to art theorists. Inspired by e.g. actor-network theory scholars such as Tony Bennett (2005) for example have argued how museum collections can be seen as "civic laboratories", that is, as "machines" or instruments for the production and subsequent governance of public identifications with moral orders embedded in e.g. staged exhibitions. Museums, in other words, are machines of control. It doesn't take a stretch of the imagination to see the relevance of Bennett's thesis for our work, or for legal semiotics in 
general. The legal theorist Nathan Moore (2007) has explored this point in quite some detail. Using Deleuze's work as a guide Moore argues that in late modern forms of life governance is more about the control, in the sphere of aesthetics, of affect through the production and circulation of icons, than about the production and circulation of conceptual forms of legality or jurisprudence. If this is the case then public art and, for reasons set out above, monumental landscape art in particular, is becoming ever more important in an age of "iconic control". It becomes ever more important, then, to tease out elements of "iconic control" in works such as The Angel of the North, or the Anglo-Saxon Warrior, or the Golden beacon.

It is to these sculptures that we are about to turn. To repeat, the point of the exercise is not to offer the final interpretation and analysis of said works of art. In light of what we have discussed above such a goal would be very little short of absurd. The point is, on the one hand, to see how similar conditions of economic downfall and matching social despair have, in different localities, led to the production of totemic landscape sculptures, but also, on the other hand, to note how the three sculptures are quite different in visual appearance. It is this difference that invites further elaboration.

\section{The Angel of the North}

Designed by Antony Gormley, and physically assembled by Ove Arup

\& Partners Engineering, the $60 \mathrm{ft}$. high, 208 ton heavy Cor-Ten 
weathering steel mass of the Angel has become one of the most "iconic" landmarks in Britain ever since 1998 when it was erected in Gateshead in North East England (most of the factual information about the sculpture in this section is taken from an illustrated book, Making and Angel, published by Gormley and the Gateshead Borough Council on the occasion of the actual construction and emplacement of the work in 1998). Gateshead was until the 1970s an industrial centre with a considerable concentration of shipbuilding activity, coalmining, and steel making. Much of this heavy industrial activity has disappeared since, but the local authorities have succeeded in at least partially facilitating a transition to service economy activity and general engineering. Elsewhere in the North East of England similar developments have taken place (e.g. with car assemblage in Sunderland). This process of economic restructuring was already on its way when in 1993 Gateshead Borough Council decided to draw up a shortlist of renowned artists with an eye on commissioning a monumental sculpture. The council is one of those in the UK, and particularly in North East England, who have used public art as a tool in their urban regeneration strategies (Sharp et al. 2005). They have over the years commissioned numerous works of art in the city centre. This has led to processes of gentrification, and the borough has been able to attract professionals to the city. Eventually the idea arose for the commissioning of a monumental landscape sculpture. 


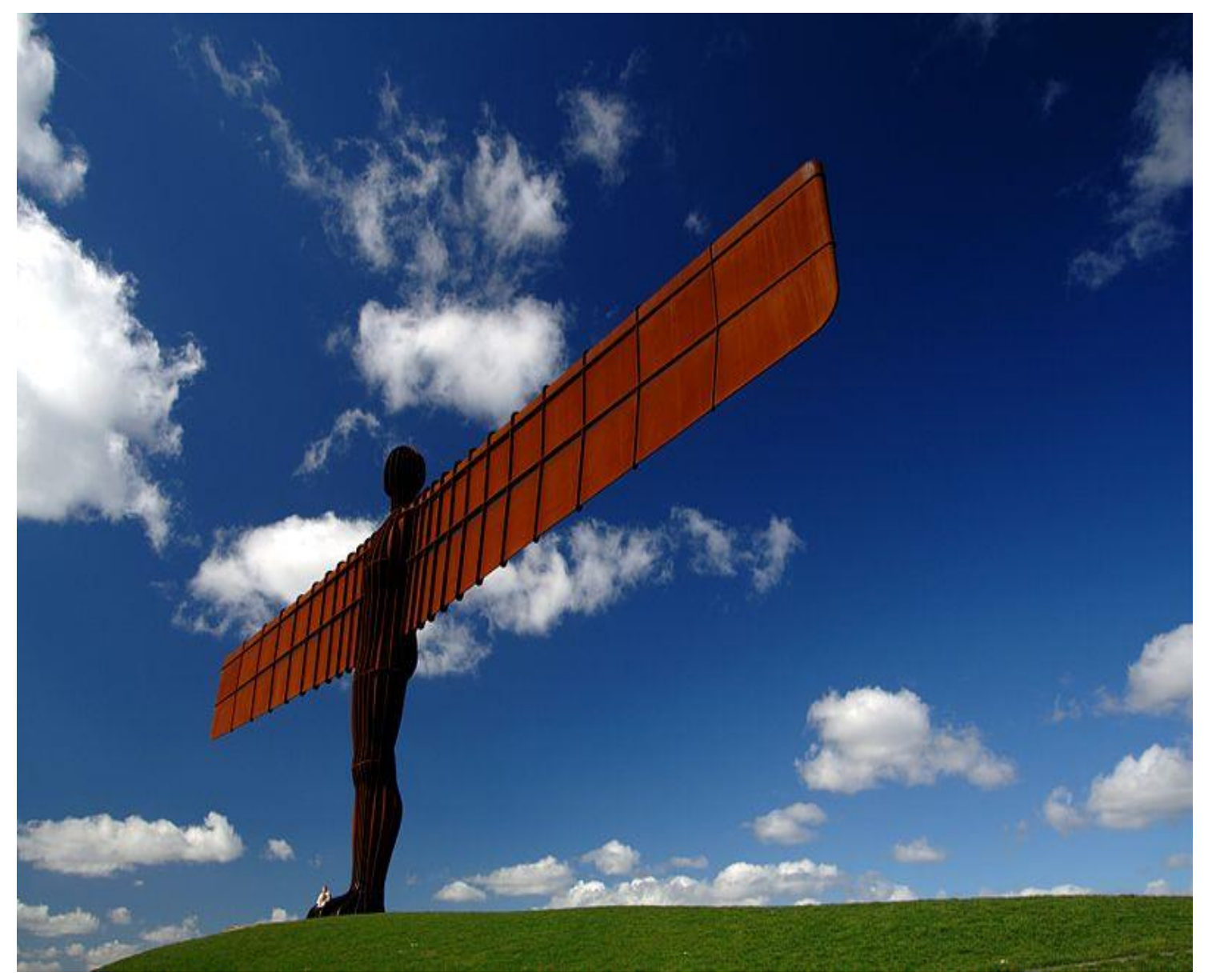

Figure 1

The Angel of the North, in Gateshead.

Designed by Antony Gormley.

Photograph by David Wilson Clarke.

Creative Commons (attribution 2.5 generic license)

The council ultimately commissioned Gormley, an internationally renowned sculptor. They were inspired by one of his earlier angels, the life-size A Case for an Angel (1990), which consists of a cast of the sculptor's own body (many of Gormley's sculptures are based on a cast of his own body) and two long, slender wings attached horizontally. Gormley was asked to design a monumental angel which would be erected at the location of an old colliery. A mound was prepared on site using the detritus of an earlier industrial age that was 
available at the derelict site. The site itself is located at the outskirts of the borough, in the open landscape. At the foot of the mound though there are a few school buildings, industrial sites, football pitches, residential estates and, of course, heavily used roads to and from the borough's city centre. The sculpture is visible from miles around.

Local residents were not involved in the commissioning process. This probably explains, at least to some extent, why the sculpture attracted a serious amount of local criticism when the designs for the Angel were first made public. A number of public engagements (e.g. educational projects with school children) managed to stem the barrage of criticism somewhat, but the bulk of hostility only gradually dissipated after the sculpture was actually completed in situ. The actual sculpture, rising high above the very earth out of which it emerged, seems to have struck a chord with most residents (and visitors alike) and it still does. It occasionally attracted severe criticism though from critics such as Mark Hutchinson who tends to describe Gormley's reluctance to engage with public "complexities or sensitivities" as "authoritarian" and "patronising", and the Angel itself as "[embodying] cultural division". (2002: 432-435).

The Angel of the North is now one of the most recognisable, iconic landmarks in the UK (Pollock and Paddison 2010: 335). It is important to note that the monument was given the name Angel of the North, and not, for example, 'The Gateshead Angel' (or some such name). The Angel is meant to represent something about the North, or at least 
about the North East of England. The sculpture, so to speak, has regional territorial ambitions. One could argue that somewhere in the sculpture, there is an active desire to bind a territory, and to bind a variety of populations on that territory to the land, and to each other. There is something totemic about the Angel and there is probably little coincidence in the fact that some commentators immediately made a connection, possibly in a nostalgic fashion, with Britain's Dark Age past. In his essay on the Angel, 'Achieved anonymity' (in Gormley et al. 1998: 27-29) the poet lain Sinclair immediately evokes a world of "Vikings, clansmen, raiders", of "cathedral and castle", "dark buildings", "memorial stones" and "Celtic crosses". The sculpture, he continues, is a "scrapyard totem pole to activate the prejudices of Middle England". The phrase "totem" or "totemic" it should be noted in passing, has also been used by Gormley himself (e.g. in Beatrix Campbell's essay on 'Gateshead and the Angel', in Gormley et al. 1998: 53-55). "What it wants", Gormley says, "is to be totemic" (1998: $55)$.

This totem, in other words, is not just binding the North and the Northerners together. The Angel desires to generate and establish Northern totemic law. But it also differentiates the totemic law of the North -a law with mythical and indeed megalithic Dark Age origins (see also Gail-Nina Anderson's 'Angels' in Gormley et al. 1998: 105-107)from the law of Middle Englanders, i.e. the more or less conservative middle class residents of more southern regions. There is a cultural and 
economic North - South divide in Britain. The Angel, clearly, is the Angel of the North.

In his essay on 'Of coal and iron and ships and planes' (1998: 14-15), Antony Gormley himself is at pains to stress that the work is both nostalgic and forward looking, and avowedly transformative. It is, he writes, about "witnessing and marking in time and space, taking now into then, being a focus for life and its dreams. Our dreams". The Angel is not to "reinforce a dominant hierarchic social order or represent an ideology". The sculpture, then, is not so much about expressing and "reinforcing" the orders that already exist. The Angel is, rather, a machine for the transformation of orders: "an energiser, focus and resonator" of that which is, certainly, but with an eye on "extending the imaginative into the physical and vice versa". What the Angel is meant to be doing, then, is to suck up, straight from the very historical potential that is flowing underneath its concrete-and-metal earthy roots, those energies that could still be used to transform the orders and the codes of The North in such a way as to make them fit for a dream of a future. And that, i.e. this code of nostalgic transformation, Gormley seems to suggest, is the very code that the Angel itself embodies. This is the code that has emerged, first virtually, and then in the steely flesh of extensive matter, from the intensive depths that lurk, inexhaustibly, under the Angel's scrapheap mound. This is the totemic law that the Angel is radiating outward (don't the wings look like aerials?) in attempts to lay it down ("extending the imaginative") onto the 
"physical" territory (and "vice versa", the sculptor adds) in a bid to produce a "collective subjective" (to evoke another of Gormley's phrases).

The "vice versa" is important here. Not only does the Angel machine aim to transform dark (Dark Age) energies and resources -and those include Ove Arup \& Partner's surviving iron ore smelting and engineering skills- into dreamt futures. It is also sensitive to what lives in the outside (the "physical", out there), and is constantly trying to pick up things from the world out there and use that to continuously improve the internal code of The North. The Angel's wings, in other words, might also be antennae that are constantly scanning the ether for anything in the wide open world (e.g. the world of global investment capital) and then transmit all of that to the internal code (the totemic law of the regenerating North) for further, unrelenting adjustment. The Angel's totemic machine -the transformative "energiser"- seems to be a slightly paradoxical one. On the one hand it expresses the regenerative activity that is already ongoing in the North East but on the other it also relies on signs from the outside to keep this internal regenerative momentum going. The Angel is a coded and coding machine that is positioned, virtually, between the intensive, dark earth of deep local history on the one hand and, on the other, the open, extensive thin blue skies ("Our dreams!") of outward-looking futures. 
The Angel, Gormley writes, is a "bridge". It "bridges[s] the earth and the sky" (1998: 15). One would be inclined to agree. As a bridge it is, perhaps inevitably so, a multiplicity (on this see also Beatrix Campbell's aforementioned essay). It combines and integrates, almost unobtrusively, opposites. It is earthy (what could be earthier than concrete and heavy iron, forged in fire). It is heavenly (what could be more heavenly than a lightly feathered angel?). An inescapable mass of concrete and steel, it is one. It is, however, also multiple: it emerged out of a bewildering variety of Northern contexts, identities and histories. It is delicate (the feminine quality of the angel's buttocks and its gently bulging genital area have often been commented upon) but it is also brutally masculine (this is an angel clad in a terrifying exoskeleton). It is both local and global. It is welcoming (its aeronautically designed wings are spread open wide as in an embrace). But there is also a barely veiled threat emanating from the spread wings. This angel could very well also be an avenging one or, perhaps, a defiantly protective guardian angel, a sentinel. Angels have been known to do all kinds of things on their messenger travels between heaven and earth. The Angel is universal. It is, after all, just one more cast of Gormley's body ("Achieved anonymity", says lain Sinclair). But the Angel is also singular (like all other Gormley body casts this Angel emerges in a very particular context). It is a Phoenix, permanently rising up from its own ashes in an endless eternal return. But it is also an immobile and immovable Moloch, firmly anchored in 
deep rock, ready to brave anything that the world throws at it. It is, writes Gail-Nina Anderson in her already mentioned essay on 'Angels', "a Blakean angel of Dark Satanic Mills, yet is has also been claimed as a defiantly positive symbol of local regeneration" (1998: 107). The Angel's enigmatic multiplicity and ambivalence, or, as Anderson concludes, its ambiguity and its hybrid composition, and its "borderland" position (1998: 106), are perhaps one of the reasons why the original protest and oftentimes downright hostility that were levelled at it during its design stage gradually crumbled away after 1998. Many residents, visitors or passersby who find themselves standing under its wings are grasped by its code, its law that seems to spur them on, to "energise" them to reflect not just on the sculpture itself, but also, and more importantly, on their relationship with it, and their relationship with The North. Many may recognise something of themselves in the Angel. The work, to use Nicholas Davey's words, may have succeeded in "fusing" the "gulf" between the spectator's "horizon" and the artwork's, "without denying either" (2005: 138-139). The Angel, one could say, has managed an almost impossible, angelically divine feat: to be all things to all people. This angelic machine seems to very good at capturing life's excessive intensive potential and allowing it to flow freely, virtually and extensively, in spectators' reflections and murmurings, and accepting the results of these reflections and murmurings back again. 
But let us now move southwards, to North Staffordshire in the West Midlands.

\section{The Anglo-Saxon Warrior (on his knees), and the Golden beacon}

Stoke-on-Trent used to be an important industrial centre in North Staffordshire ("The Creative County"). Coalmining, steelworks, but more importantly perhaps, ceramics and pottery industries, were, until the 1970s, predominant, not just locally, but regionally as well. The city of Stoke-on-Trent is actually a federation of six smaller towns. The city has no real centre (although one of the towns has, over the years, grown into a de facto commercial centre). It was and remains a sprawling, polycentric collection of a number of more or less separate localities.

The decline of the aforementioned industries since the 1970s has left the area with significant levels of economic and social deprivation. Successive local governments and authorities have so far struggled in their attempts to turn the tide. Efforts have been made to regenerate the city's economic infrastructure and to attract more affluent populations to the city. Even though the immediate area boasts two institutions of higher education the process of economic restructuring has so far not delivered anything like significant success. Newly implanted industries are largely in the retail sector and have not been able to kick-start processes of gentrification. Attempts were made though to create a proper "Cultural Quarter" which was located in one of the towns, and which includes a Pottery Museum and Art 
Gallery, theatres and civic centres, but again without significant gentrification or regeneration effects. The name "Cultural Quarter" is actually physically signposted throughout the area. One of the problems that keep hampering any attempt at regeneration seems to be the enduring poly-centricity of the area. In addition to internal rivalry and competition between the towns for cultural budgets and public or private investment there is always the quite simple issue that any regeneration effort is almost inevitably bound to yield geographically scattered and incoherent results.

In 2009 a metal detectorist stumbled, in a field near Lichfield, in the south of Staffordshire, across what later would appear to be a hoard from pre-Conquest times. The Anglo-Saxon Hoard, as it became known, includes hundreds of precious artefacts. It is believed, by archaeologists, to be a collection of battle spoils dating back to the $7^{\text {th }}$ or $8^{\text {th }}$ centuries, deep into Dark Age history. For some reasons that will forever elude us those that, all those centuries ago, placed the hoard in the ground were unable to retrieve it at a later point in time. The Pottery Museum and Art Gallery at Stoke-on-Trent managed to secure a portion of the hoard for a permanent exhibition on their premises. This success stirred quite some congratulatory debate in the local press and ultimately led to a decision to commission a local sculptor (Andrew Edwards) to complete a life size (9 ft) statue of an Anglo-Saxon warrior. Edwards completed the work in 2012. The warrior, adorned with the kind of attributes that were found in the hoard, was sited at the Pottery 
Museum in the same year. The more important issue though here is that at the time of its emplacement the local press speculated on the possibility and necessity for Stoke-on-Trent to emulate Gateshead and erect a monumental $(60 \mathrm{ft})$ version of the warrior in the open landscape along one of the main traffic arteries that cut through the city's polycentric urban sprawl. In some versions (pictures were posted on the internet) the massive warrior statue would be kneeling (on one knee).

The statue never materialised and remains a figment of the imagination in some quarters of the local press. But as a figment of the imagination it is an important one. The idea of a monumental landscape sculpture in the form of an Anglo-Saxon warrior only emerged in Stoke-on-Trent after a detectorist happened upon a hoard, dating back to the Dark Ages, some 30 miles to the south. The image that seems to have sprung to mind makes no reference to Stoke-onTrent's recent, painful industrial past. The image is one of a giant warrior, brought to his knees, glued to or drawn back to Dark Age earth. The fact that no reference is made here to the recent industrial past, and the skills, lives, identities, aspirations and hopes in it, is, one could argue, quite telling. Let us explore this image.

The first aspect of this image that one might note is that the warrior is not really local. It is an Anglo-Saxon warrior, and, archaeology suggests, probably one of Mercian extraction (the ancient Kingdom of Mercia covered much of what we would now call the Midlands). The 
imagined statue, in Stoke-on-Trent, is, then, not just saying something about Stoke itself, but also, and crucially, about a region. The law that it speaks, and the law that it might wish to lay down -if law at all there be in this case- is one that should speak to a number of populations on a territory. This warrior's law -the warrior code, so to speak- is one in which a desire to bind, to integrate is alive. In this respect the imaginary Anglo-Saxon Warrior has something totemic about it. But could it ever achieve anything like integration? Could it serve as an "energising machine" of connection amidst the levels of geographical disconnection and additional economic despair in a place like Stokeon-Trent? One could perhaps be forgiven for having some doubts here. The warrior makes no connection with those issues and seems to be moving beyond them, backwards in time into deep, very deep and dark history. It is as if any connection with the recent and current predicament of the Stoke area would be too painful to even contemplate. This warrior dwells resolutely in the dark earth of a bygone Ur-age, a time before and beyond all calamities that would, much later, befall Stoke-on-Trent. This dark earth, one could say, is the dark earth of Mercia, the dark earth of pure potential, before any of it (i.e. this pure potential) was spent and wasted on towns, roads and industries that have, we now know, only led to the scrapheap of history. The warrior does not want to be reminded of all this misfortune. He flees from it, straight into the myth of a pure past, a dark earth age when potentiality was still full and complete, unspent. 
The word 'misfortune' above was used on purpose. In this imaginary, events occur mostly through luck or coincidence. One buries a hoard but misfortune prevents one from unearthing it later. One stumbles across an age old hoard. One happens upon a new invention, as Josiah Wedgwood did when, in the $18^{\text {th }}$ century, he conducted, in a place that we now call Stoke-on-Trent, thousands of experiments with chemicals in a bid to find the one winning composite ceramic glaze. One waits for events to happen in more southern areas. One waits. No spark of genius here. There seems to be no "machine" doing any "energising" here either. There is no assemblage of codes, no virtual law, so to speak, operating in the background. In this imaginary there is precious little code at all. What little of productive, engine-like code there is only seems to be murmuring: "Stick as closely as possible to the earth, to pure potential. Allow the intensive flows there to do their work. Just wait for something to hit you. Be patient, you will stumble across something interesting, maybe a hoard that someone left in the ground, ages ago".

Much in the Anglo-Saxon Warrior seems to be pointing to the earth. In the version of the kneeling warrior this attraction to the raw earth of uncoded potential is even more noticeable. One wonders whether the warrior, still on his knees, is actually trying to get up on his feet again, or if he is, on the contrary, falling to the ground, struck by the sword of a conquering force. It may of course be quite a bridge too far to read in this image a reflection of Stoke-on-Trent's sorry predicament, its last 
stand, as it were. But it seems worthwhile to speculate how, in a place like Stoke-on-Trent which has hitherto been unable to "energise" itself, and which has not yet managed to "machine" or even "fabulate" itself (to use Bergsonian parlance) new futures, the image of an earthbound, stricken warrior looms large in the imagination. In this imaginary there is little engagement with the region's recent past. There is little opportunity to come to terms with it. There is almost no place, in this imaginary, for a virtual law -a set of codes- to crystallize out of the scattered and disconnected detritus of a mangled geography and a historical debacle. The Dark Age warrior, in a way, represents the flight from any such engagement. It is a flight to and into the one thing that, in this imaginary, one can be certain of: raw earth, that which was already there before all else happened. The earth is the only place where things happen. The earth is where one finds things. The dark earth, this Dark Age earth, is the only place with energetic intensity.

But this flight from engagement, and the subsequent lack of a coded, legal productive machine at the virtual heart of the imaginary, leaves the warrior with nothing to project onto the surrounding landscape, and nothing to "lay" onto the territory. The warrior has no antennae, and no aerials to beam out his law into his extensive surroundings. There is nothing to beam out. There is little to bind populations and land together under a "law of the land". There's only dispersion, disconnection, and dereliction on the surface of an eternal soil of pure, un-coded, unformed potential. 


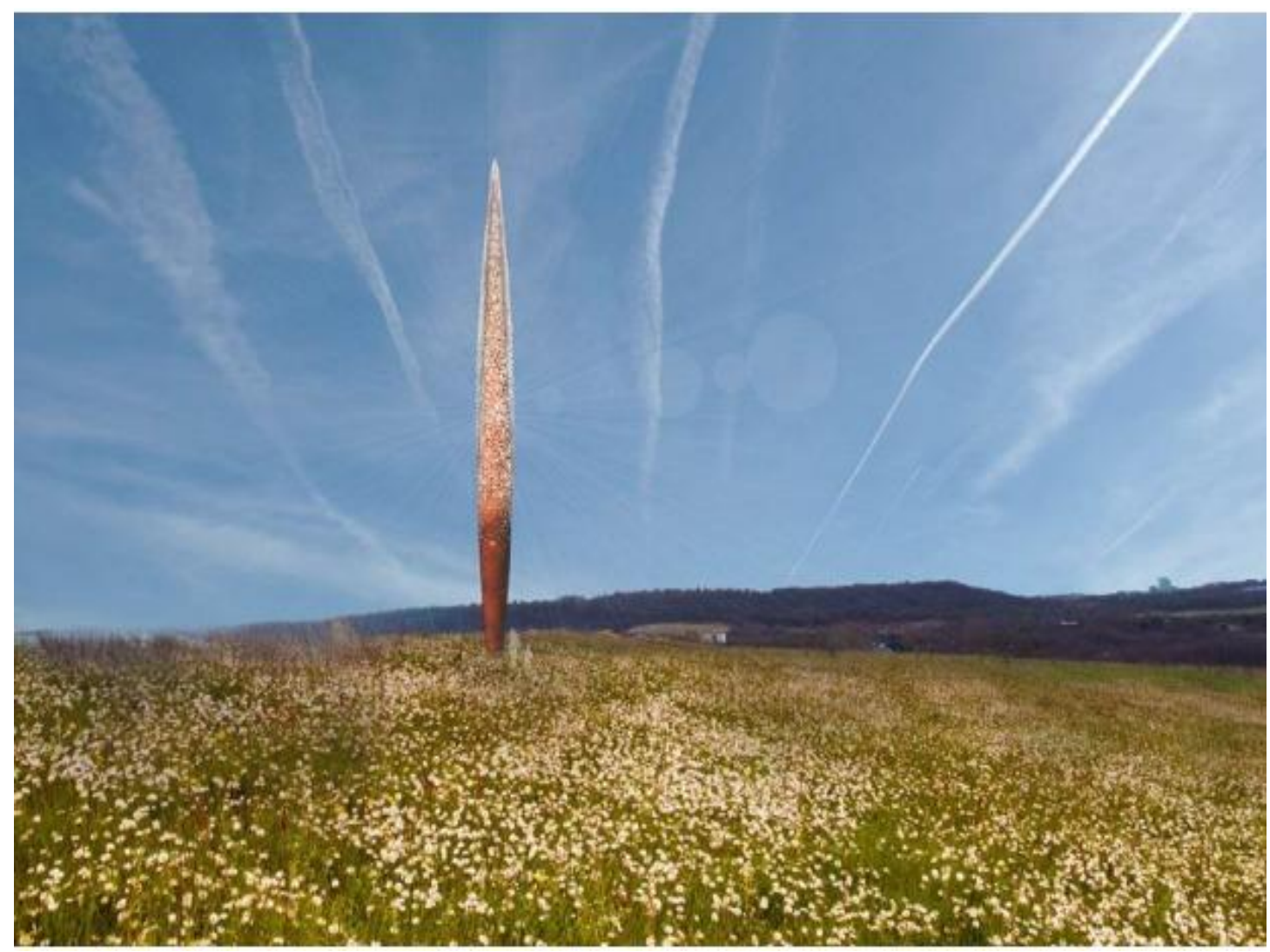

Figure 2

Simulation of Golden sculpture.

Designed by and (C) Wolfgang Buttress.

Courtesy of Wolfgang Buttress.

All this is not to say that there is no place in Stoke-on-Trent for aerials and antennae. On the contrary: the local borough council eventually, i.e. in 2011 , decided to commission sculptor Wolfgang Buttress, whose proposal was chosen out of a list of 200 submissions, to create a monumental landscape sculpture (as it says in a report of a local council meeting posted on 12 April 2011 on a local blog, mytunstall.co.uk). This led to a sculpture, Golden, destined to be sited at the location of the now defunct Goldendale Ironworks in Tunstall (one of the six Stoke-on-Trent towns). The work is, at the time of writing, 
still in the process of being assembled with the help of a local steelworks. It "will be taller than the Angel of the North" local journalist Emma Davies writes in the local newspaper The Sentinel (posted there on 11 October 2013). The sculpture has the appearance of a slender torch. It consists of a Cor-Ten steel shaft ("the same materials as the Angel of the North", Buttress is cited as stressing in The Sentinel on 9 November 2012), $61 \mathrm{ft}$ high, on which approximately 1,500 stalks are placed. At the top of each of those stalks is a glass prism with a light. Each of the prisms holds a message from residents (including schoolchildren) in the area. The messages are about the residents' and children's "wishes" and "dreams" (Buttress cited in the aforementioned blog at mytunstall.co.uk). Golden has been described as a "beacon". It is destined to beam the "wishes" and the "dreams" of Stoke's current generations into the ether. It is, in a way, a distress beacon. It sends out a call for help to all those, out there, who may, one day, happen upon the signal.

One could say that the sculpture is, once again, a "found" one. The work shows some familiarity with some of the sculptor's earlier work. Buttress has elsewhere already built and emplaced monumental torchlike constructions (e.g. the $66 \mathrm{ft}$ high Dream), while another of his earlier creations, Golden Dew, consists of arrangements of rows of coloured stems topped with sizeable "dew" drops. Moreover, the beacon only sends out calls. It does not seem to be built with signal reception in mind, let alone internal signal transmission and signal processing. One 
would need a "transformative machine" for that, and this (i.e. a "transformative machine") is what is lacking in the Golden beacon. Like the warrior, Golden is unable to connect the intensive energies of the earth with realisations in the extensive sphere. To be clear, an attempt was made. The sculptor, Wolfgang Buttress, has himself stated that the choice of materials (weathering steel, the light in the prisms) is meant to suggest connection with the former ironworks (cited in a post by Lucy Rove in The Sentinel on 9 November 2012). But the emphasis of Golden, one could argue, is clearly on its function as a beacon. The virtual, coded machine of transformation, that is, its totemic law, so to speak, which would be the device that could make such a connection, is missing, just as it was missing in the warrior. Whereas the warrior fled into the intensive energy of the earth, the beacon only manages to send out signals about wishes and dreams into the thin, extensive expanse of the ether. There is then very little in the way of productive transformation. In this reading the fact that the messages will be sealed into their prisms (never to be reopened) is quite telling. In the Golden imaginary the wishes and dreams are not expected to ever be in need of adjustment. The Golden's distress call is expected to remain valid for ever.

In short, and in conclusion, in both the Anglo-Saxon Warrior and the Golden beacon there seems to be certain lack of articulation between on the one hand intensive potential and extensive realisation. It is as if the "machine" in the middle, the coded machine of transformative 
totemic law, is missing. Both sculptures, each in their separate ways, seem to have fled from it, albeit in opposite directions.

\section{Coda}

There is something about post-industrial landscapes. What once gave a certain level of regularity and coherence to the experience of time and space now only survives in scattered bits and pieces, quite visibly so. In some cases the need is then felt to make a gesture in an attempt to regain some of the lost coherence, and to re-generate some modicum of commonality, a common law so to speak, a new "law of the land" that could somehow bind the territory and those on it under the sign of a totem. The totem then is the embodiment of the new law of the land. It receives the raw elements for the fabrication of the new law from the scattered histories and identities all around it, re-codes and transforms them, and lays down the resulting law.

But no two totems of course are alike. No two territories are alike, not even in a world that is fuelled by abstract global capital. No two desires, no two decisions to recode the law of the territorial lands are alike. In this paper we have made an effort to explore and contrast in quite some detail two recent attempts in the UK to deploy massive monumental landscape sculpture in a bid to institute, in the wake of industrial collapse, what we have termed here "totemic law". The first of those attempts took place in the North East of England and resulted in the $60 \mathrm{ft}$ high Angel of the North in Gateshead. The second is still 
ongoing in North Staffordshire in the West Midlands and is, at the time of writing, likely to end in the construction and emplacement, in 2014, of a $61 \mathrm{ft}$ Golden beacon.

What has remained largely beyond the scope of this essay is the issue of how the members of the territorial tribes themselves affectively experience the totem, how they reflect upon it, how they give it meaning, and how they make use of all that in their "fabulations" (to evoke Henri Bergson one last time) of a communal, territorial life (for an overview of the bio-phenomenological, cultural and individually psychological complexities involved in this, see e.g. Joy and Sherry 2003; Belfiore and Bennett 2007). That could and perhaps should be the topic of another essay.

\section{References}

Barron, Anne. 2000. Spectacular Jurisprudence. Oxford Journal of Legal Studies 20, 2: 301-315

Belfiore, Eleonora and Oliver Bennett. 2007. Determinants of impact: towards a better understanding of encounters with the arts. Cultural Trends 16, 3: 225-275

Bennett, Tony. 2005. Civic laboratories. Museums, cultural objecthood and the governance of the social. Cultural Studies 19, 5: 521-547

Bergson, Henri (1911) [1907] Creative Evolution. New York: Henry Holt \& Co. 
Bergson, Henri. 1967 [1932]. Les deux sources de la morale et de la religion. Paris: Presses Universitaires de France.

Beunders, Henri. 2007. The end of arrogance, the advent of persuasion. Public art in a multicultural society. Social Analysis 51, 1: 42-57

Blum, Andrea et al. 1989. From the other side: public artists on public art. Art Journal Winter: 336-346

Bonnett, Alastair. 2009. The dilemmas of radical nostalgia in British psychogeography. Theory, Culture \& Society 26: 45-70

Burk, Adrienne L. 2006. Beneath and before: continuums of publicness in public art. Social \& Cultural Geography 7, 6: 949-964

Clements, Paul. 2008. Public art: radical, functional or democratic methodologies? Journal of Visual Arts Practice 7, 1: 19-35

Cordes, Joseph J. and Robert S. Goldfarb. 2007. Decreasing the 'bad' for mixed public goods and bads. The case of public sculpture. Eastern Economic Journal 33, 2: 159-176

Cruikshank, Jeffrey and Pam Korza. 1988. Going public: a field guide to developments in art in public places. Amherst: University of Massachusetts Arts Extension Service

Davey, Nicholas. 2005. Aesthetic $f(r)$ iction: the conflicts of visual experience. Journal of Visual Art Practice 4, 2-3: 135-149 
Deleuze, Gilles \& Felix Guattari (1980) Mille Plateaux. Paris: Editions de Minuit.

Deutsche, Rosalyn. 1996. Evictions. Art and spatial politics. Cambridge: The MIT Press.

Diamond, Beth. 2004. Awakening the public realm: instigating democratic space. Landscape Journal 23: 22-39

Fitzpatrick, Peter. 2001. Modernism and the grounds of law. Cambridge: Cambridge University Press.

Fleming, Ronald Lee with Melissa Tapper Goldman. 2005. Public Art for the Public. The Public Interest Spring: 55-76

Gormley, Antony and Gateshead Metropolitan Borough Council. 1998. Making an Angel. London: Booth-Clibborn Editions.

Hamilton, Juliet, Leslie Forsyth and Daniel De Jongh. 2001. Public art: a local authority perspective. Journal of Urban Design 6, 3: 283-296

Hawkins, Harriet. 2012. Geography and art. An expanding field: site, the body and practice. Progress in Human Geography 37, 1: 52-71

Hutchinson, Mark. 2002. Four stages of public art. Third Text 16, 4: 429438

Jancovich, Leila. 2011. Great art for everyone? Engagement and participation policy in the arts. Cultural Trends 20, 3/4: 271-279 
Joy, Annamma and John F. Sherry. 2003. Speaking of art as embodied imagination: a multisensory approach to understanding aesthetic experience. Journal of Consumer Research 30: 259-282

Kelly, Michael. 2001. Public art controversy: the Serra and Lin cases. Journal of Aesthetics and Art Criticism 54, 1: 15-22

Kwon, Mwon. 1997. One place after another: notes on site specificity. October 80 Spring: $85-110$

Leder, Helmut, Benno Belke, Andries Oeberst and Dorothee Augustin. 2004. A model of aesthetic appreciation and aesthetic judgments. British Journal of Psychology 95: 489--508

Levine, Caroline. 2002. The paradox of public art: democratic space, the avant-garde, and Richard Serra's 'Tilted Arc'. Philosophy \& Geography 5, 1:51-68

Levinson, Sanford. 1998. Written in stone. Public monuments in changing societies. Durham: Duke University Press

Miles, Malcolm. 1997. Art, space and the city. Public art and urban futures. London: Routledge

Miles, Malcolm. 2005. Interruptions: testing the rhetoric of culturally lead development. Urban Studies 42, 5/6: 889-911

Moore, Nathan. 2007. Icons of control: Deleuze, signs, law. International Journal for the Semiotics of Law 20: 33-54 
Phillips, Patricia. 1989. Temporality and public art. Art Journal Winter: 331-335

Pollock, Venda Louise and Ronan Paddison. 2010. Embedding public art: practice, policy and problems. Journal of Urban Design 15, 3: 335356

Princenthal, Nancy. 2003. In praise of anachronism: on public art and its critics. ArtUS 24-28

Selwood, Sara. 1995. The benefits of public art. The polemics of permanent art in public places. London: Policy Studies Institute.

Sharp, Joanne, Venda Pollock and Ronan Paddison. 2005. Just art for a just city: public art and social inclusion in urban generation. Urban Studies 42, 5/6:1001-1023

Tilghman, Benjamin. 2006. Reflections on aesthetic judgment and other essays. Aldershot: Ashgate.

Visconti, Luca, John Sherry Jr., Stefania Borghini, and Laurel Anderson. 2010. Street art, sweet art? Reclaiming the 'public' in public space. Journal of Consumer Research 57, October: 51 1-529

Wagner, A. (2011) French urban space management: a visual semiotic approach behind power and control. International Journal for the Semiotics of Law 24, 2: 227-242

Wagner, A. 2014. Game of power within the French urban landscape: A socio-legal semiotic analysis of communication, vision and space. International Journal for the Semiotics of Law 27, 1:161-182 